\title{
Undergraduate Research Supervision in Social Studies and Religious Education: The Case of Primary Colleges of Education in Botswana
}

\author{
Keene Boikhutso $^{1}$, Baamphatlha Dinama ${ }^{1}$, Santudu Kebabope ${ }^{2}$ \\ ${ }^{1}$ University of Botswana, P/Bag, 702, Gaborone, Botswana \\ ${ }^{2}$ Serowe College of Education, P/Bag 009, Serowe, Botswana \\ *E-mail: dinamab@mopipi.ub.bw
}

\begin{abstract}
This paper explored the myriad problems associated with undergraduate research supervision in social studies and religious education using one of the primary Colleges of Education near Gaborone, the capital city of Botswana as a case study. The study applied qualitative research involving interviews and focus group interviews to solicit information from eight college lecturers and ten final year students doing research in Religious Education and Social Studies. The respondents were purposively selected on the basis that they would provide rich data on the supervision of research projects. Additional information was generated through document and content analysis. The findings revealed that supervisors and student teachers at undergraduate level experience a large array of problems related to research capacity. The students, for example lacked presentation skills which has resulted in failure to present original work. There is also evidence of a relatively inadequate supervisory skills by college lecturers in terms of executing their supervision duties. The study concludes by calling for both supervisors and their supervisees to consider undergraduate research as a two-way process which requires expertise and adequate skills.
\end{abstract}

Key words: undergraduate, research, supervision, religious education, social studies, curriculum, supervisor, supervisee, knowledge, skills

\section{Introduction}

The introduction of research projects as part of the assessment for the requirement for the award of a Diploma in Primary Education (DPE) is a relatively recent development in teacher education in Botswana (Serowe College of Education Prospectus, 2009). The Revised National Policy on Education (RNPE) of 1994, Government Paper No. 2 called for the introduction of the Three Year Diploma in Primary Education in the quest to provide quality education, training and create an opportunity for lifelong learning (Republic of Botswana, 1994). The DPE programme aims at preparing primary school teachers in several academic areas including Social Studies and Religious Education.

Social Studies and Religious Education have until recently been taught in one department in the Colleges of Education. The DPE programme is divided into two components, content referred to as Academic Studies while the method component is referred to as Professional Studies. These two components are taught concurrently throughout the programme while the third, the research component receives limited attention. The key emphasis is placed on teaching and learning process, methods, techniques and strategies of teaching rather than research and publication. The objectives of the DPE programme include the need to:

a) help student teachers develop their own teaching styles by exposing them to a variety of methods of teaching, e.g. inquiry and group work. 
b) develop lessons that use the national principles of education, namely Democracy, Development, Self-reliance, Unity and Botho (loosely translated means respect for humanity) help student teachers to emphasize the importance of developing pupils' skills and attitudes and thinking skills of discovery, observing, recording, classifying, problem-solving, attitudes of appreciation, compassion and cooperation (Social Studies Tutors' Guide, 1990: 37-38).

These objectives highlight the need for the learning and teaching processes to be student-based, promote problem-solving skills and the creation of new knowledge. The introduction of research projects is seen as one of the ways of promoting these competencies. The integration of research component into the DPE programme is consistent with the ideals espoused in the National Development Plan (NDP) 10 (Republic of Botswana, 1985), and the national Vision 2016 (Republic of Botswana, 1997), For instance, one of the seven pillars of Vision 2016 is to transform Botswana into a 'knowledge society' with research and innovation as cornerstone of development (Republic of Botswana, 1997) . According to Tabulawa (2009) what is articulated in these government documents represents the country's response to globalization which purports to produce a learner, worker, and citizen whose attributes include creativity, versatility, critical thinking and problem-solving skills. Research projects presumably promote these attributes. As stated earlier, Botswana's educational philosophy is based on the national principles of democracy, development, self-reliance, unity and Botho. The term botho is a Setswana word used to describe a person who has a well-rounded character, well-mannered, courteous and disciplined and having respect for other people.

Currently Botswana has seven colleges of education. Three of these are primary colleges of education and the fourth college has recently being decommissioned due to poor infrastructure and teaching facilities. There are also two secondary colleges of education, one college of arts and technology and one college of technical and vocational education. Adeyemi and Hopkin (1997) note that the primary and secondary colleges of education are affiliated to the University of Botswana (UB) and offer programmes which qualify teachers for the Diploma in either primary or secondary education There are, however, on-going plans to transform the colleges into the degree offering institutions. Presently, the colleges provide courses on academic study and practice designed to facilitate the professional development of primary and junior secondary school teachers. The function of UB is to provide advice regarding programme improvement and ensuring quality outcomes. The Social Studies moderation report (University of Botswana, 2008) captures the lecturers' responsibility of teaching and the supervision of research projects, while UB undertakes the moderation of the programme as a whole as part of quality control and assurance measures (University of Botswana, 2008) .

Davis, Evans, and Hickey (2006) rightly regard research skills as crucial for the successful operation in a global knowledge economy. Tabulawa (2009) concurs by adding the need for the promotion of lifelong learning and professional development. While academics argue as a rule that a general grounding in research skills and understandings at the undergraduate level will result in receptiveness to research and informed consumption of new information that carries through into professional life, there are some like Diezmann (2005) who caution that the development of research skills works best for individuals who are motivated towards research but this does not necessarily work for all pre-service teachers.

\section{The Problem}

The realities of supervising undergraduate research projects at primary colleges of education are aptly captured in the reflections and experiences of one of the investigator's (also shared and appreciated by the other two investigators who at some point taught as staff development fellows before becoming lecturers in the colleges of education) when she/he observed that:

(C) 2013, European Journal of Educational Research, 2(1), 37-50 
when I was appointed as Staff Development Fellow in [one of the primary Colleges of Education] in the Department of Social Studies, two weeks after I had assumed duty, I was approached by three students (Specializing in Social Studies) who wanted me to supervise their projects. Having been told it was part of my duty, I agreed to take the supervision role. I only had Bachelor of Education (Primary) which I had acquired from the University of Botswana. I felt insecure as I had never taken any research methods course during my period of study; I had to do my duty anyway. That was a daunting task; I survived through collegial collaboration and reading a few textbooks on research methods. Whether or not the projects were good enough and consistent with what was expected is yet to be proved. The students got passing scores and acquired their certificates (Personal memoirs, 2010).

From this account it is clear that the investigator's personal and professional experiences as a Staff Development Fellow in the colleges of education has prompted the need to investigate problems associated with the supervision of undergraduate research projects in Social Studies and Religious Education (RE). The main emphasis was to investigate the lecturers' competencies, knowledge and skills related to research supervision. Research supervision at undergraduate level has been going on since the introduction of research projects as part of the changes that emanated from the recommendations of the Revised National Policy on Education (Republic of Botswana, 1994). Literature on research supervision in general addresses key issues that need to be dealt with to effectively carry it out. However, very little on undergraduate research supervision in Social Studies and RE in Botswana has been done. As such, a study of this kind is critical for investigating the challenges which are presented by the research processes in primary colleges of education.

The investigators have persistently observed that college supervisors appear to display a sense of self-doubt and uncertainty in guiding and supporting students' research projects. This is evidenced by remarks such as, "Supervising research is such a tedious and demanding exercise" and, "I'm not certain if I'm confident enough to supervise these students". In our view, comments like these do not support a dedicated research effort and indicate an element of self-doubt regarding research supervision. The comments are also likely to negatively influence students' attitudes and the way they approach research. In addition, we have come across instances where a few students have changed supervisors due to poor supervisor-supervisee relationships. In fact, finger pointing by those involved at college level is often the order of the day when things turn out to be working against what is expected. In short, educational research, as an activity and important component of the pre-service preparation, has been neglected for quite some time compared to other areas such as teaching practice and examinations. The main focus of this paper is to explore the actual and perceived challenges and constraints experienced by lecturers regarding Social Studies and Religious Education undergraduate research projects supervision in primary colleges of education. To further unpack the problem under investigation, this study is guided by the following research questions: a) to what extent do the research projects undertaken in the primary colleges of education promote problem-based-learning? b) what is the connection between the quality of educational research output and supervision? And c) what are the challenges of research supervision in the primary colleges of education. To answer these central questions, this study is guided by the literature on problem-based-learning, quality of educational research and supervision and challenges of research supervision at undergraduate level in higher education institutions.

\section{Problem-Based Learning}

This paper is informed by theories on scaffolding which are often used to support problem-based learning (PBL). Davies (2000) and Young (1993) define scaffolding as an instructional strategy that involves supporting novice learners to cope with the complexities associated with research supervision 
and the acquisition of research prerequisite skills. Scaffolding is a concept that is relevant as it forms the basis for finding out whether or not the supervisory process in colleges of education facilitates the acquisition of problem-solving skills. Branford, Brown and Cocking (2000) aver that at the undergraduate level, instructional scaffolding ensures the provision of sufficient support to promote learning when concepts and skills are introduced for the first time . Within this paradigm, students are encouraged to become researchers while working in small groups to analyze problems, determining solutions and evaluating problems at hand (Hodson \& Hodson, 1998;. According to Hodson \& Hodson (1998), problem-based learning is contingent upon "knowing when, where, how much, and what type of guidance, critical feedback and support are needed to facilitate effective learning and development of good learning behaviors" (p.110). This hinges on professional judgment that is derived from theoretical understanding, experience and thoughtful reflection on supervisors' support. Hodson and Hodson (1998) further contend that letting students wade through unscuffolded tasks in the name of learnercenteredness is not advisable because students do not have the experience to translate theory into practice. This is particularly true in the context of colleges of education in Botswana where students just tread on research activities without having been exposed to research methods courses. In this theory, students are assisted in gaining conceptual and procedural knowledge while encouraging them to help them develop flexible thinking skills (Hmelo-Silver, Duncan \& Chinn, 2007; Kirschner, Sweller \& Clark, 2006).

\section{Quality of Educational Research and Supervision}

The quality of educational research is central to higher education institutions such as colleges of education. The quality of research has implications for educational reform and in particular curriculum development and learning approaches. In other words, successful research depends on the quality of supervisors who are resourceful and innovative. Ideally, supervisors have to do a lot of research in order to meaningfully guide, supervise and develop the academic aptitude of the novice researchers.

Quality research is an important component of the curriculum in teacher preparation. This linkage is attributable to the philosophical influences of John Dewey (1988) who advocated for studentcentered methods of teaching that comprise inquiry, problem-solving and discovery approaches. Dewey (1988) further noted that learning through experience and doing is of paramount importance in that it develops intellectual potential in the learner. This is based on the assumption that problem-solving leads to the production of knowledge and the development of critical thinking skills, habits and attitudes necessary for learners to solve a wide variety of problems of which research is a component.

The relationship between the supervisor and the student is a key factor in the success of the research project. This relationship should involve professionalism, compromise, mutual understanding, honesty and respect of other people's opinions and judgments. Wisker (2005) and Schaffner (2004) posit that the student-supervisor relationship is affected by many issues which require the attention of the supervisor. Ideally, this relationship has to be purely pedagogic and not familial and intimate. Extending the boundary beyond supervision is more likely to complicate the supervisory relationship, so it is upon the supervisor to determine the limits of the relationship.

Zhao (2003) sees research supervision as a continuous process whereby both the supervisor and the supervisee learn. In other words, it is a two-way process where two parties are in a reciprocal learning whereby, for example, supervisors learn to know the area being researched hence being able to provide appropriate feedback to the supervisee. 


\section{Challenges of Research Supervision}

Past studies for example, (Armstrong \& Shanker, 1983; Lumadi, 2008; Mutula, 2009; Zhao, 2003) reveal that there are multiple challenges, constraints, and complexities associated with the process of research supervision both at undergraduate and post graduate level. Some of the challenges relate to the nature of supervision, lack of research skills by students, students' characteristics and incompetence by lecturers. This is confirmed by Grant (2003) and Lee (2007) who suggest that supervising research involves complex academic and interpersonal skills. For example, there are times when the supervisor is frustrated by the seemingly lack of progress made by the student. This is particularly true where the student does not seem to take into account the suggestions made by the supervisor. There is also the lack of commitment by the student towards their research. Similarly, a student, may be upset with what they perceive to be inadequate guidance they receive from the supervisor due to lack of expertise. For example, Kincheloe (2003) advised that supervisors need to have the necessary academic qualification for them to be actively involved in research activities. It is also important that they take into consideration ethical issues such as acts of misconduct and plagiarism (Berg, 2007; Howe \& Moses, 1999; Penslar, 1995). Another challenge is that of supervisors who are hardly available for consultation and if ever available, they provide negative feedback like this is "poor work" and "this is not a research topic". Such comments are not helpful as they tend to discourage and demotivate students. In the long run this may affect the whole project from the taking off stage to the completion of the report (Bell, 2005; Johnston 2000). To this end, Grant (2001) and Shannon (1995) see an open and frank discussion as crucial for a healthy relationship between the supervisor and the student. This also has the potential to avert potential misunderstanding between the two parties

The problem of poor supervision of undergraduate research is compounded by lack of students' motivation. This is partly attributable to lack of prerequisite research skills, limited access to resources such as Information Technology (IT), poor support due to heavy staff and student workloads. In addition, limited understanding of research, inadequate research capacity coupled with a non-supportive supervisory relationship are more likely to lead to loss of the student's confidence on supervisors (Shaw, Holbrook, Scevac \& Bourke, 2008; Wisker, 2005; Remenyi \& Money, 2004; Shannon, 1995).

\section{Methodology}

The paper adopted a qualitative research methodology involving interviews and focus group interviews to solicit information from the participants in one of the primary colleges of education located in a periurban area of Tlokweng near Gaborone. Additionally, document and content analysis were used to collect data. The population comprised eight college lecturers, of which four were Social Studies while the other four were Religious Education lecturers. These were purposively selected on the basis that they would provide rich data on the supervision of research projects. Ten final year students doing research in Religious Education and Social Studies were also purposively sampled. Five of them specialized in Social Studies while the other five specialized in Religious Education. Data collected was analyzed and synthesized through the use of thematic approach to provide some patterns which formed the basis of the interpretation. In order to ascertain that the rights of the participants were not violated, an informed consent was sought, and this involved explaining the purpose for which the investigation was carried out as well as any possible benefits or lack of it. The participants were assured that their responses would be treated as confidential and that they were to remain anonymous and they had the right to withdraw from the sudy anytime they wished to. 


\section{Findings}

\section{Students' Research Competencies and Skills}

Six of the sampled college lecturers reported that many students do not have the requisite research skills and competencies. One of the participants observed that:

Students' level of communication is very poor, there are only a few who can write impressive scholarly assignments. The rest need to really work hard to reach the standard we want. One cannot carry out quality research without pre-requisite skills.

Another lecturer Mr Gibbs reported that students show lack of skills in research at the initial stage of topic selection as they fail to come up with researchable topics. Accordingly:

Our students do not have research skills; this is an area of utmost concern. They fail to come up with researchable topics. No presentation skills, they transcribe data into their work without acknowledging. This is not deliberate; they are just ill-prepared to undertake research. Some students' write-ups and construction of ideas is so bad that numerous corrections have to be made with every submission; some even fail to follow what they were instructed to do. It is very frustrating. Some of them hardly ever come for consultations, unless you follow them up because if as a supervisor you neglect them you will also be failing in your duties.

The lecturer further pointed out that students are quick to blame lecturers. Mr Gibbs emphasized:

We have had cases of plagiarism, although only a few. One case I still remember is where a student copied a project from another student who had completed his studies two years back. Cases of plagiarism are hard to detect but where a student goes on for a long time without meeting his or her supervisor and only comes at the end to submit his or her work often raises a cause for concern. We usually start investigations in instances like this one. It is usually wise for lecturers to have a record of previous topics as this makes plagiarism to be easily detected. Some projects are duplicates, over the years we have students writing the same topic but only changing the wording not the meaning.

Furthermore, Ms Bera expressed her unhappiness regarding her student's lack of time management. She said that "sometimes she keeps on postponing doing her work only to find out later that she has wasted a lot of time". Essentially, this seems to be a problem for most of the students who lack time management skills, hence a need for motivation and encouraging students to commit most of their time to academic work. Postponement of work is also an indication of self doubt where the student is uncertain of what to do, hence resorting to buying time.

\section{Lecturers' Research Competencies And Skills}

The lecturers' views regarding research were a clear indicator of their skills and competencies.

\section{Mr Sergio:}

I can say I'm fairly competent, however there are areas where as a supervisor I do feel I'm not competent enough and need help. Again, research supervision is all about collaboration because sharing ideas often helps. You know if maybe we had clearly defined roles and a way of doing things as a college that could go a long way.

(C) 2013, European Journal of Educational Research, 2(1), 37-50 


\section{Mr Damon:}

Supervising is a continuing process of learning; you cannot say it is enough. It also depends on the type of student you are dealing with. I have to emphasize however, that supervising is quite taxing while teaching experience alone is inadequate since it requires appropriate skills.

\section{Ms Greg:}

There are times when you tend to get confused especially when you are new in the practice. We do not have adequate skills, yes, we have done research but it is not a guarantee that we have the required skills to supervise. At times we feel hesitant to fiddle too much with the topic because it can end up changing the student's original focus.

It appears that college lecturers somehow unwillingly embrace their role as supervisors since it is part of their job. In fact, their commitment to research is generally suspect. Mr Faku:

We supervise in different ways. Individual lecturers have strengths in various areas of supervision. Personally, I'm not good enough. I have my strengths and weaknesses. I have to be honest to declare that sometimes I feel overwhelmed with this whole responsibility.

\section{Mr Tiro:}

In other areas of supervision I'm okay, that is, guiding students through topic selection and other research procedures. The problem is that I do not have skills in the new computer software, for instance, data analysis packages such as SPSS. If for instance, the student has used Microsoft Excel, I cannot tell whether he or she is correct or not. I cannot even demonstrate to the student what he or she is supposed to do concerning the software.

\section{Ms Saba:}

We use experience when supervising students in their project work. We are not offered formal training. If I remember well we once requested to have training on supervision. A promise was made but to date it has never taken effect.

\section{Students' perceptions of the quality of research supervision}

One of the students, Grace, pointed out that they do not get adequate guidance from their supervisors and complained that lecturers are not "skillful in doing their job" hence the problems they encounter even when it comes to choosing a topic. Ricca elaborated that:

Even if you try to guide yourself with past projects, it does not make a difference because most of the students did not do well, to me if you do not do well in something which has been supervised, it means the supervisor failed you. We do not have research skills and the time allocated for research is too little for amateurs, even if the supervisor tries to exercise patience time becomes a problem and one may not complete on time. We really have a problem.

Benajmin pointed out that his supervisor in particular was not certain with the decisions as she kept on "changing every time. For example, today she will say this and the next day something different during our meetings". This suggests that if the students are given conflicting feedback that may confuse them and also shows that the supervisor may not be certain about what should be done. Other problems include lack of consistency and commitment and the tendency to persistently postpone scheduled meetings by college lecturers. 
Some of the students however, were positive about the guidance they received from their supervisors. For instance, Simon noted "I am satisfied with my supervisor. The problem is with me because he always tells me what to do and I am the one who just fails to do what is expected of me". Similarly, Mark remarked positively though casually that the lecturers "have the skills but they do not have enough time to attend to us. I think our supervisors are doing fine, it is just that some of us take research casually and we fail to take initiative for our own learning". Several students pointed out that the lecturers were doing their work and that the main problem was the busy schedules of both the supervisors and the students hence both parties were unable to meet regularly. It is evident from the above findings that college students held divergent views regarding the quality of research supervision they received at college.

\section{College Lecturers' Understanding of Their Supervisory Role}

The sampled lecturers expressed that they understood their supervisory role as involving mentoring and inducting the students into research processes. Mr Faku said that he understood his role of supervising a research project in terms of the multiple roles played, such as guiding students to pick researchable topics providing professional guidance and counseling because the research process can be very frustrating. Mr Tiro also added that his role was "to see to it that the student follows proper research procedures and this can be done through coaching and opening up to the student in case he or she needs help". Similarly, Ms Saba explained her role as one of guiding the students throughout their research project and she indicated that she had to "impart relevant skills to my supervisee and refer him or her to relevant materials to assist in planning his or her project. My role is to see through the student's completion of his or her project through guidance and advice".

\section{Supervisor-Supervisee Relationship}

Some supervisees were positive about the guidance they received from their supervisors. For example Rolex said:

My supervisor is very good. He cares a lot about my progress, it is only recently when we seemed to have very little time to meet. He complains if I do not come for discussions, which I think is good, this shows that he is concerned about my work. He says I should try to manage time in order to complete the project. My supervisor is very friendly and always gives me direction; he makes research an interesting experience.

Tebbie was also positive about her supervisor when she indicated that she always explains clearly what is expected of her. According to Tebbie, "my supervisor encourages me to do my work thoroughly and because of this I think I will succeed. She always says 'you can make it, most of those who came before you have made it so will you". Tebbie, however, indicated that there are instances when the supervisor tended to worked under pressure The same was said by Bernard about his supervisor:

Whenever I need help from him, he is there and when we meet he is always willing to help. The main problem is that at times he is too busy with other assignments and it gives us very limited time for conferencing. He is quite friendly though.

There were contrasting views from other students as expressed by Kago: 
It seems our supervisors have very little interest in our work, sometimes you think you are bothering them because of the attitude they display. They keep on postponing the meetings until one gets discouraged and sits back. Some even say 'Do you think a college lecturer can wait the whole day in the office for a student? I have other things to do'.

Sitta echoed Kago's sentiment when she said:

Lecturers are unfriendly. There is no cooperation between students and their supervisors. My supervisor dictates a lot. When I need help it's like I'm bothering her. She is a fault finder. All she does is give destructive criticism which does not help me. Right now I am left behind due to her unsupportive attitude. When I bring in a piece of work she would ask me in a hostile manner like 'where do you get this from? I cannot work with people who just do what they want'. She once blamed me for being a student in the mature entry programme.

Some students said that their supervisors exhibited authoritarian attitude towards them hence that put tremendous strain on them. This is how Salu described his relationship with his supervisor:

I don't enjoy my research topic because it was indirectly imposed on me. When I complain she becomes angry and blames me for undermining him. In situations like this, I choose to keep quiet and maintain my cool to avoid spoiling working relationships any further.

\section{Alleviating supervision challenges: the perspectives of lecturers and students}

It is clear that there are several challenges regarding research project supervision. For example, $\mathrm{Mr}$ Tembo emphasized the need for new approaches to research supervision by exposing students to problem-solving and critical thinking skills. He also suggested that: "Lecturers need to be formally inducted into the supervisory exercise because supervision needs expertise for it to be effective". In the same vein another lecturer Mr Tumo opined that:

Lecturers need to be trained on effective ways to supervise research projects; they need to know proper procedures to follow and how much they should expect from students. Right now individual lecturers use their experience and discretion to guide students. Having a common understanding on research procedures could curb misunderstandings and differences that often arise among lecturers due to diverging views on which decision to take on what is best for the students.

Adding on to what other lecturers preferred, one of the senior lecturers, $\mathrm{Mr}$ Bobo had this to say:

We were long promised training courses on research supervision which never materialized, that would have been the most appropriate way to approach research supervision. This should be coupled with standard research supervision guidelines for colleges of education.

Asked how training could be carried out, Mr Bobo suggested that "At the beginning of the first term a training session for research supervision could be carried out for at least one week and all staff members who are to supervise research projects should be part of this exercise. It should be run every year". One Head of Department Ms Marah blamed the college-based research committee for not carrying out its mandate adequately as she strongly alluded that: 
It is high time the research committee took a more active role on issues concerning research supervision. Members of this committee should not just ask for submission of projects when they are due and leave the rest to lecturers. It should be an advisory body which ensures that projects are adequately supervised. It should also see to it that workshops are organized for the students and lecturers on research skills. For now very little has been done.

Another lecturer Mr Daniso saw the issue differently and pointed out that:

The whole programme for colleges of education needs restructuring in order to accommodate rigorous research. There is need to have time set aside for research projects and they should not run alongside other activities. As of now research is done within an already congested schedule.

Ms Carrim expressed a similar feeling and indicated the need for introspection on research processes at college and lamented the inadequate teacher preparation prevalent in the colleges of education. She further reminded that moderators have long advised on how research could be improved "but so far no action has been taken and students continue to do badly in research". Ms Naro added that there were no "well defined guidelines of supervision while the environment is not supportive enough because facilities are poor and the administration is not supportive".

Rojas, a student, echoed the lecturer's concern when he said "the problem with research in our college is that it takes place side by side with other activities such as lecture sessions so we do it under pressure, we write tests, do presentations and write assignments. Research should be allocated special time with no other activity". He also added that they had for a long time expressed their displeasure at the present arrangement because it has a negative impact on their academic performance.

Thabo suggested that before students can embark on research they should be introduced to basic research skills which are presently not offered to students. He further indicated that both students and supervisors need to have time to discuss the direction of the supervisee's research project. She further pointed out that "doing research without any research orientation was a heavy burden on our side as the lecturer in charge of supervision would be talking a language a student does not understand". Betty added that the students can do a better job if they did "research related activities in class before we can take individual research. If we can be given topics in groups before dealing with our own topics, it can help a lot". It is clear from the comments of Betty, Thabo and Rojas that students are not given adequate skills in terms of exercises related to research. For example Jethro said:

Our supervisors need to discuss with us what they want us to do. They need to motivate and adequately guide us. I strongly feel that our lecturers should organize workshops for us where we can share research skills. We also must do some collaborative mini projects before doing individual work. In that way, skills gained in mini projects would be transferred to the final research work".

Students were also unhappy with the one day in a week that is set aside for research activities. Manu expressed her unhappiness on the issue when she said:

The one day reserved for research in a week is not enough. Two days is better! We need more time. Research should be allocated its own time with no other activities tied to it. Look here, 
if the supervisor is not available on the set day, one has to wait for the following week, and most lecturers are always engaged in some other activities.

\section{Discussion}

The findings of this study revealed that supervisors and student teachers at undergraduate level experience a large array of problems related to research capacity. This is confirmed by Mutula (1999) and Grant, (2003) who revealed that research supervision at undergraduate level is an exercise plagued with a multiplicity of complexities and challenges which are mainly evidenced in students' research outputs. On the part of the students, it was discovered that they lacked presentation skills which has resulted in failure to present original work. This is partly attributed to the absence of research methods courses and inadequate supervision. In addition, there is evidence that lecturers possess inadequate skills to enable them to effectively execute their supervision duties. There is scarcity of research expertise, inexperienced supervisors, and some supervisor work in disciplines that are outside their areas of specialization. This has resulted in low research outputs lack of proper monitoring and general laxity in the way research is carried out. It must be noted however, that supervision of projects at undergraduate level is considered in the same level as teaching hence there are no supervision training opportunities for college lecturers.

The study has also revealed that the students' and supervisors' expectations are most of the times at variance mainly because they are not clearly spelt out, which consequently has implications on the quality of research outputs. Other concerns such as administrative and institutional support systems have also tremendously intensified the magnitude of the problems that already exist. There is need for both the lecturers and the students to be committed and show a considerable amount of self-motivation if they are to succeed in their work. There is counter accusation between lecturers and students, for example, lecturers accuse students of being lazy and lacking commitment while students accuse lecturers of lacking expertise. Although training is another dimension that needs attention, effective supervision can also be enhanced through team work. This kind of working relationship may probably establish congruence between goals and expectations of the research process.

These findings have two implications. One is that ill-preparedness in embarking on research limits intellectual development of the students and their ability to be effective in creating their own knowledge-base. Second, these results are consistent with past studies for example, in the view of Mutula (2009) inadequate research competencies at undergraduate level often leads to poor research outputs.

The results also suggest that college lecturers tend to approach research supervision differently and are aware of their strengths and challenges. Besides, they appreciate the complex and dynamic relationships between the students and lecturers which need to be nurtured. However, it can be deduced that not all lecturers are absolutely incompetent as it may appear to be on the surface. The skills and gap identified by a few lecturers needs prompt attention in order to improve the quality of research supervision. These results are consistent with Kincheloe's (2003) observation who warns against the dangers of taking research supervision casually. Yet in the opinion of Richardson-Koehler (1988) quality supervision is contingent upon certain skills and competencies that supervisors are expected to possess

Contrary to claims made by college supervisors that they encourage students'to think independently when making decisions- they however, did not clearly spell out how they actually put their ideas into practice. For example, supervisors consistently view their role in terms of guiding, coaching, mentoring and providing an atmosphere that is conducive to learning. While it can argued that this approach to supervision is somewhat helpful, but at the same time it limits students' academic flexibility and autonomy. Supervisors seem to adopt a more directive role which is capable of 
stultifying the intellectual and personal development of students. This kind of approach does not seem to give the student the liberty to be an independent researcher. It rather gives the lecturer the dominat role of making decisions for the student which contradicts democratic learning approach. This markedly contrasts with the view by Wisker (2005) and Pearson and Kayrooz (2004) that research supervision is a facilitative process that allows students to own their research.

The study also illuminates the relationships between the students and their supervisors. Students' reflections during interviews of their relationship with their supervisors help us to appreciate that they have different levels of satisfaction, connectedness and closeness to their supervisors. However, the most critical implication underlying these responses exemplifies how overlapping student characteristics are and how their personal interaction with their supervisors can impact on their academic work. The reflections also highlight the challenges obstructing the creation of a friendly environment where both parties are committed and competent enough in pursuit of quality research. To a large extent, the participants' comments suggest that supervisors who are enthusiastic and possess good interpersonal skills are likely to bring positive outcomes in terms of quality research. Hammick and Acker (1998) observe that for a healthy working relationship, supervisors and their supervisees need to show sensitivity and work collaboratively. Supervisors need to display effective leadership skills and avoid being overly critical and subjective as this can inhibit students from developing their own style of writing. Novices need supervisors who they can confide in, with whom they can share their views, and willing to give unconditional advice and encouragement.

The findings reveal that many participants are disgruntled about the supervision process. Lecturers' experiences point to the fact that there are various factors affecting the smooth running of research supervision. This entails making improvements such as training supervisors and the restructuring of the whole undergraduate programme. Furthermore the findings are also in agreement with the contention of Remenyi \& Money (2004) who argue that institutions of higher education should ensure that a training course on research supervision is a pre-requisite for research supervision. Similarly, Schaffner (2004) complements this view by pointing out that developing skills in research supervision is a gradual process that needs to be strengthened through training. According to Remenyi and Money (2004) those entrusted with research supervision should demonstrate a continuing professional development which requires participation in research activities at a personal level. To a larger extent, a combination of these approaches can bring about a significant and desired change to research supervision at undergraduate level.

\section{Conclusion}

The study unearthed several misconceptions which have previously been held by college lecturers associated with research supervision in Social Studies and RE at undergraduate level. It disconfirms allegations usually leveled against students on their supposedly negative attitudes and lack of commitment to their work. It also underscores the responsibility entrusted on the lecturers to adequately supervise students' projects regarding their preparedness to do so. It clearly came out in the findings and the extant literature that low motivation levels and lack of commitment are a result of naivety in research procedures. It must be admitted as literature has revealed that research supervision at undergraduate level while complex and taxing, it equally requires expertise and competence. The findings have undoubtedly proved supervision to be a two-way process which requires expertise and adequate skills from both the supervisor and the supervisee.

\section{References}

(C) 2013, European Journal of Educational Research, 2(1), 37-50 
Acker, S., \& Hammick, M. (1998). Undergraduate Research Supervision: A Gender Analysis. Studies in Higher Education, 23 (3), 335-347.

Adeyemi, M.B. \& Hopkin, A.G. (1997). University affiliation and the role of the university in the moderation of teaching practice in Botswana. Higher Education 33 (415-431), 417-418.

Armstrong, M. \& Shanker, V. (1983). The Supervision of Undergraduate Research: Student perceptions of the supervisory role. Studies in Higher Education. 8 (2), 177-183.

Bell, J. (2005). Doing Your Research Project. Buckingham: Open University Press.

Berg, (2007). Qualitative Research Methods for the Social Sciences. Boston: Pearson Education, Inc.

Botswana, Republic of (1994). The Revised National Policy on Education. Gaborone: Government Printer.

Brandford, J.D., Brown, A.L. \& Cocking, R. (2000). How people learn. Washington DC: National Academy Press.

Davies, H., Evans, T. \& Hicky, C. (2006). A knowledge-based economy landscape: Implications

for tertiary education and research training in Australia. Journal of Higher Education Policy and Management, 28 (3), 231-234

Davies, P. (2000) Approaches to evidence-based teaching, Medical Teacher, 22 (1), 14-21.

Demircioglu, I.H. (2008). Learning How to Conduct Research in Teacher Education: A Turkish Perspective. Australian Journal of Teacher Education. 33 (1)

Dewey, J. (1988). Experience and Education. New York: Library of Congress in Publication Data.

Diezmann, C. M. (2005). Growing scholarly teachers and educational researchers: A curriculum for a research pathway in pre-service teacher education. Asia-Pacific Journal of Teacher Education, 33(2), 181-193.

Grant, B. (2003). Mapping the pleasures and risks of supervision. Discourse: Studies in the Cultural Politics of Education, 24(2), 175-190.

Hammick, M. \& Acker, S. (1998). Undergraduate research supervision: a gender analysis, Studies in Higher Education, 23 (3), 335-347.

Hmelo-Silver, E. C., Duncan, G. R., \& Chinn, A. C. (2007). Scaffolding and achievement in problembased and inquiry learning: a response to Kirschner, Sweller, \& Clark (2006), Educational Psychologist, 42 (2), 99-107.

Hodson, D., \& Hodson, J. (1998). 'Science Education as Enculturation: Some Implications for Practice', School Science Review, 80 (290), 17-24.

Jarolimek, J. (1986). Social studies in Elementary Education. New York: Pearson Education Inc.

Johnston, S.(2000). Research supervision-setting the scene. In A. Holbrook \& S. Johnston (Eds.), Supervision of postgraduate research in education. Victoria: AARE (pp. 17-31).

Kincheloe, J. L. (2003). Getting Beyond the Facts: Teaching Social Studies/Social Sciences in the Twenty-first Century. New York: Peter Lang.

Kirschner, P. A., Sweller, J., \& Clark, R. E. (2006). Why minimal guidance during instruction does not work. An analysis of the failure of constructivist, discovery, problem-based, experimental, and inquiry-based teaching, Educational Psychologist, 41, 75-86.

Lumadi, M.W. (2008). The Pedagogy of Postgraduate Research and Its Complexities. College Teaching Methods \& Styles Journal, 4 (11), 25-32.

Moses, S. M. \& Howe, R. K., (1999). Ethics in educational research, Review of Research in Education, $24,21-60$

Mutula, S.M. (2009). Challenges of Postgraduate Research: Global Context, African Perspectives. Proceedings of DLIS $10^{\text {th }}$ Conference Held on $25^{\text {th }}$ November 2009 at Tuzi Gazi Conference Centre, Richards Bay, South Africa.

Pearson, M. \& Kayrooz, C. (2004). Enabling Critical Reflection on Research Supervision Practice. International Journal of Academic Development, 9 (1), 99-116 
Penslar, R.L. (1995). Research Ethics: Cases and Materials. Indiana University Press.

Remenyi, D. \& Money, A. (2004). Research Supervision: For Supervisors and Their Students. London: Academic Conferences Limited.

Richardson-Koehler, V. (1988). Barriers to the effective supervision of student teaching: a field study, Journal of Teacher Education, 39 (2), 28-34.

Republic of Botswana (1991). Primary Education Improvement Project:, The tenth and Final Report. Gaborone: Ministry of Education Republic of Botswana, (1994). Revised Policy on Education, Gaborone: Government Printers

Republic of Botswana, (1997). Presidential Task Group for a Long Term Vision for Botswana: Vision 2016. A Summary. Gaborone: Government Printer.

Republic of Botswana, (1985). National Development Plan 10.. Gaborone: Government Printer.

Salia-Bao, K. (2000). African Social Studies Programme. Ibadan: Evans Brothers.

Schaffner, C. (2004). Formalizing supervision-A step towards better quality? Birmingham: Aston University. (Report from Lisbon Congress round table on supervision).

http://www.est translationstudies.org/Research\%20issues/Formalising\%20supervision.htm. Retrieved 10 May, 2010

Serowe College of Education (2009-2010). Serowe College of Education prospectus.

Shannon, A.G. (1995). Research Degree Supervision: 'more mentor than master'. Australian University Review. 2: 12-15

Social Studies Tutor's Guide for The Primary Teacher Training Colleges in Botswana (1990). Gaborone:Ministry of Education. Government Printers.

Tabulawa, R.T. (2009). Education Reform in Botswana: reflections on policy contradictions and paradoxes. Comparative Education, 45 (1), 87-107.

University of Botswana (2009-2010). Graduate Student's Handbook. Gaborone: University of Botswana.

Unniversity of Botswana (2008). Social studies Moderation Report, Gaborone: Centre for Academic Development - University of Botswana.

University of Botswana (2009). Report of the Task Group on the 'Future of Graduate Research Supervision at University of Botswana. Gaborone: School of Graduate Studies- University of Botswana.

Wiersma, W. (1991). Research Methods in Education: An Introduction. Boston: Allyn and Bacon.

Wisker, (2005). The Good Supervisor: Supervising Postgraduate and Undergraduate Research For Doctoral Theses and Dissertations. Hampshire: Palgrave Macmillan.

Young, M.F. (1993). Instructional design for situated learning. Educational Technology Research and Development, 41(11), 43-58.

Zhao, F. (2003). Enhancing the Effectiveness of Research and Research Supervision Through Reflective Practice. http://ultibase.rmit.edu.au/Articles/July03/zhao.pdf_Retrieved 19 April, 2010.

(C) 2013, European Journal of Educational Research, 2(1), 37-50 